\title{
Effects of nitrogen supplementation on yeast (Candida utilis) biomass production by using pineapple (Ananas comosus) waste extracted medium
}

\author{
Rosma, A. * and Cheong, M. W. \\ Food Technology Division, School of Industrial Technology, Universiti Sains Malaysia,11800 Penang, Malaysia \\ E-mail: rosmah@usm.my
}

\begin{abstract}
Pineapple waste medium was used to cultivate yeast, Candida utilis. It served as the sole carbon and energy source for the yeast growth. However, pineapple waste media contain very little nitrogen $(0.003-0.015 \% \mathrm{w} / \mathrm{v})$. Various nitrogen sources were incorporate and their effects on biomass, yield and productivity were studied. Significant $(p<0.05)$ increment on biomass production was observed when nitrogen supplement (commercial yeast extract, peptone, ammonium dihydrogen phosphate, ammonium sulphate and potassium nitrate) was added into fermentation medium. Commercial yeast extract, Maxarome ${ }^{\circledR}$ which increased $55.2 \%$ of biomass production at $0.09 \%(\mathrm{w} / \mathrm{v})$ nitrogen content, is the most suitable among the selected organic source. On the other hand, ammonium dihydrogen phosphate at $0.09 \%$ (w/v) nitrogen content is comparable inorganic source which enhanced $53.7 \%$ of production. Total nitrogen content of each treatment at $0.05 \%(\mathrm{w} / \mathrm{v})$ showed that nitrogen supplied was not fully utilized as substrate limitation in the fermentation medium.
\end{abstract}

Keywords: pineapple waste; nitrogen; fermentation; yeast biomass; Candida utilis

\section{INTRODUCTION}

Fermentation comprises the oldest and largest application of microbial technology. It is a biotechnological application with modern forms of industrial production utilizing living organisms, especially microorganisms, and their biological processes. It involves conversion of carbohydrates and related components to end products such as acids, alcohols and carbon dioxide (Bamforth, 2005). Organisms employed in food fermentations are many and diverse; however they are principally lactic acid bacteria and yeast. Yeast from genera Candida, Saccharomyces, Torulopsis and Lipomyces are able to transfer carbon source from carbohydrate to lipid while the protoplasm contains high in glyceride, phospholipid and ergosterol. Yeast extracts (YE) are concentrates of the soluble components of yeast cells (Sommer, 1998) and can be a good source of supplement for protein deficient diet. YE has been mainly used as flavour enhancers contributed by its nucleotides and amino acid components (Nagodawithana, 1992). Besides that, YE can mask bitterness or sour taste, increase aroma and serve as colouring agent or antioxidant.

Yeasts are common microorganism which can grow on fruit and vegetable processing wastes. There are several studies on bio-transformation of different agricultural waste into value-added products such as yeast biomass from salad oil manufacturing wastewater (Zheng et al., 2005a); ethanol production from non-sterilized beet molasses
(Roukas, 1996); biomass production from rice straw hydrolysate (Zheng et al., 2005b); cultivation of the yeast on pineapple cannery effluent (Nigam, 1999).

At present, pineapple wastes are not utilized for any purpose but are allowed to pollute rivers and to decompose along the roadside. Hence, pineapple wastes include cores, peels, and others unwanted part can be low-cost substrates for production of intracellular protein from yeast. Lee and Kim (2001) reported that pineapple peel waste was found to be able to yield large amount of reducing sugar such as glucose and fructose which is the disaccharide most easily utilized by yeast cell. Another advantage is that pineapple is not seasonal, thus available throughout the year (Kouakou et al., 1987). Pineapple wastes could be a good carbon source for yeast growth. However, pineapple wastes media studied had very little nitrogen content (0.003\%-0.015\%) compared to control commercial media of YEPG. Moreover, Mohd Azemi et al. (2001) reported that nitrogen supplementation was found to be essential for the growth of Saccharomyces cerevisiae and Candida utilis in POME. Thus, supplementary of nitrogen source is needed to increase the nitrogen content in the waste and thus to enhance the yeasts growth (Loo et al., 2002).

In this study, the effect of nitrogen supplementations in pineapple waste extract as medium for C. utilis biomass production was focused. Kinetic parameters of fermentation

* Corresponding author 
such as biomass yield on substrate, productivity and yield of biomass, substrate consumption were analyzed.

\section{MATERIAL AND METHODS}

\section{Microorganism and culture conditions}

Candida utilis ITM 1017, which is obtained from the Culture Collection Centre of Universiti Teknologi Mara, Malaysia was reactivated on yeast extract peptone glucose (YEPG) plate agar and incubated at $30^{\circ} \mathrm{C}$ for $4-5$ days (Belem et al., 1997). The culture was then maintained on YEPG slants at $4^{\circ} \mathrm{C}$ and subcultured every 2 months.

\section{Fermentation medium (pineapple waste medium)}

Pineapple wastes (Ananas comosus) consisting of peels, cores and unwanted parts of the fruit were obtained from a local fruit stall (Jelutong, Penang). The wastes were washed and cut into smaller pieces before the addition of distilled water at a ratio of 1:1 (w:v). The extract was obtained through heat treatment in an autoclave at $121^{\circ} \mathrm{C}$, $15 \mathrm{psi}$ for $15 \mathrm{~min}$. The extract was then filtered using Whatman No. 3 filter papers with particle retention size of 6 $\mu \mathrm{m}$ (Whatman Ltd., Maidstone, UK) and subsequently Whatman glass microfiber GF/C with a particle retention size of $1.2 \mu \mathrm{m}$ (Whatman Ltd., Maidstone, UK). Pineapple waste extract was diluted to $3^{\circ} \mathrm{Brix}$ and the $\mathrm{pH}$ was fixed at $\mathrm{pH} 4.5$ using $1 \mathrm{M} \mathrm{NaOH}$. About $1.0 \mathrm{~mL}$ medium with a total soluble solid content of $3{ }^{\circ}$ Brix was produced for every gram of pineapple waste.

\section{Shake-flask fermentation}

Loopfuls of C. utilis are used to inoculated $50 \mathrm{~mL}$ of pineapple waste broth to obtain $10^{6} \mathrm{cells} / \mathrm{mL}$, incubated at $30{ }^{\circ} \mathrm{C}$ for $24 \mathrm{~h}$ on a orbital shaker incubator at $100 \mathrm{rpm}$. For screening experiments, $7.8 \%(\mathrm{v} / \mathrm{v})$ preculture are inoculated into $50 \mathrm{~mL}$ fermentation medium with different source of nitrogen supplements in $250 \mathrm{~mL}$ Erlenmeyer flasks for $48 \mathrm{~h}$, at $30^{\circ} \mathrm{C}$ and speed $100 \mathrm{rpm}$.

\section{Effects of different nitrogen sources with different} concentration on $C$. utilis biomass

The experiment was carried out by adding $0.01 \%$ $(w / v), 0.05 \%(w / v)$ and $0.09 \%(w / v)$ nitrogen content of various types nitrogen from either organic or inorganic sources. For organic sources, two types of commercial yeast extract (Maxarome ${ }^{\circledR}$ and Gistex ${ }^{\circledR}$ ) and peptone was used while for inorganic sources, ammonium dihydrogen phosphate, $\mathrm{NH}_{4} \mathrm{H}_{2} \mathrm{PO}_{4}$, ammonium sulphate, $\left(\mathrm{NH}_{4}\right)_{2} \mathrm{SO}_{4}$, potassium nitrate, $\mathrm{KNO}_{3}$ was used. Blank pineapple waste extracted medium was prepared as control and the same condition of fermentation was carried out. Biomass of yeast cell and reducing sugar content was determined at every 8 $\mathrm{h}$ interval during the fermentation. Nitrogen content of pineapple waste extracted medium with $0.05 \%$ (w/v) supplements was determined at $0 \mathrm{~h}, 24 \mathrm{~h}$ and $48 \mathrm{~h}$ by macro Kjeldah method.

\section{Calculation of kinetic parameters}

Biomass yield on the substrate

The biomass yield on the substrate was determined as the ratio of the biomass produced to substrate consumption, according to Eq. 1 whereby the substrate was contributed by reducing sugar (Stanbury et al., 1995):

$\mathrm{Y}_{\mathrm{X} / \mathrm{S}}=\left(\mathrm{X}-\mathrm{X}_{0}\right) /\left(\mathrm{S}-\mathrm{S}_{0}\right) \quad$ Eq. 1

where

$Y_{X / S}=$ biomass yield coefficient on substrate $(\mathrm{g} / \mathrm{g})$

$X=$ biomass concentration $(\mathrm{g} / \mathrm{L})$

$\mathrm{X}_{0}=$ initial biomass concentration $(\mathrm{g} / \mathrm{L})$

$\mathrm{S}=$ substrate concentration $(\mathrm{g} / \mathrm{L})$

$\mathrm{S}_{0}=$ initial substrate concentration $(\mathrm{g} / \mathrm{L})$

\section{Biomass productivity}

The biomass productivity was calculated as the ratio of the maximum biomass concentration to the corresponding fermentation time (Stanbury et al., 1995).

\section{Substrate consumption}

The substrate consumption was determined as the ratio of the utilized substrate to the initial substrate, according to Eq. 2 whereby the substrate was contributed by reducing sugar:

Substrate consumption $=\left(S_{0}-S\right) / S_{0} \quad$ Eq. 2

\section{Statistical Analysis}

Fermentations were conducted in triplicate batches. All analysis was performed in triplicate except for total nitrogen content analysis, where duplicate analysis was carried out. The data was subjected to Duncan's Multiple Test of Statistical Package for Social Science, Version 12 (SPSS Inc., Illinois USA), where $\mathrm{p}<0.05$ was considered statistically significant.

\section{RESULTS AND DISCUSSIONS}

Feasibility of different organic nitrogen sources supplementation of pineapple extracted juice for the improvement of yeast biomass production was determined. From the result obtained, significant $(p<0.05)$ increment 
were observed with addition of organic nitrogen sources on yeast biomass. In sequence, it would have effect on biomass yield as well as productivity of $C$. utilis. Media composition plays a vital role in the improvement of efficiency and economics of microbial fermentation (Nancib et al., 2001).

The amount of yeast biomass produced in the fermentation medium containing only pineapple juice as carbon and nitrogen sources were lower than those with nitrogen supplementation. The lower yield of biomass produced in the fermentation medium containing only pineapple extracted juice was mainly due to the deficiency of nitrogen sources in this juice. Therefore, on using pineapple juice, other nitrogen sources must be added into the fermentation to support both microbial and biomass production. This is also reported by Nancib et al. (2001) that production of lactic acid by using date juice as fermentation medium could be increased by supplementing date juice with nitrogen sources. Figure 1-3 show that effect of organic nitrogen sources supplements on biomass $(\mathrm{g} / \mathrm{L})$ and reducing sugar remaining $(\mathrm{mg} / \mathrm{mL})$ of $C$. utilis grown in pineapple waste extracted medium at different concentration nitrogen content (w/v). Addition of either yeast extract or peptone into pineapple fermentation medium give significant increment $(p<0.05)$ compare to control without additional of nitrogen source.

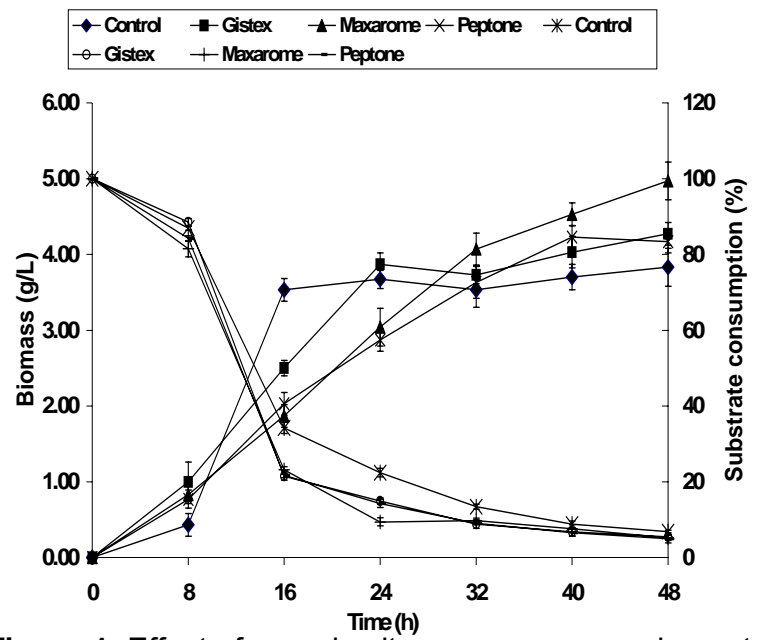

Figure 1: Effect of organic nitrogen source supplements on biomass $(\mathrm{g} / \mathrm{L})$ and remaining reducing sugar $(\mathrm{mg} / \mathrm{mL})$ of $C$. utilis grown in pineapple waste extracted medium at fixed concentration of $0.01 \%$ nitrogen content $(\mathrm{w} / \mathrm{v})$. Data are mean value \pm standard deviation of triplicate analysis of duplicate experiment

Among three organic sources, commercial yeast extract Maxarome is the best supplement for $C$. utilis growth. With addition of $0.01 \%$ of nitrogen content, yeast grown in fermentation medium with Maxarome supplement $(4.97 \mathrm{~g} / \mathrm{L})$ enhanced $28.4 \%$ biomass production compare to control $(3.87 \mathrm{~g} / \mathrm{L})$.

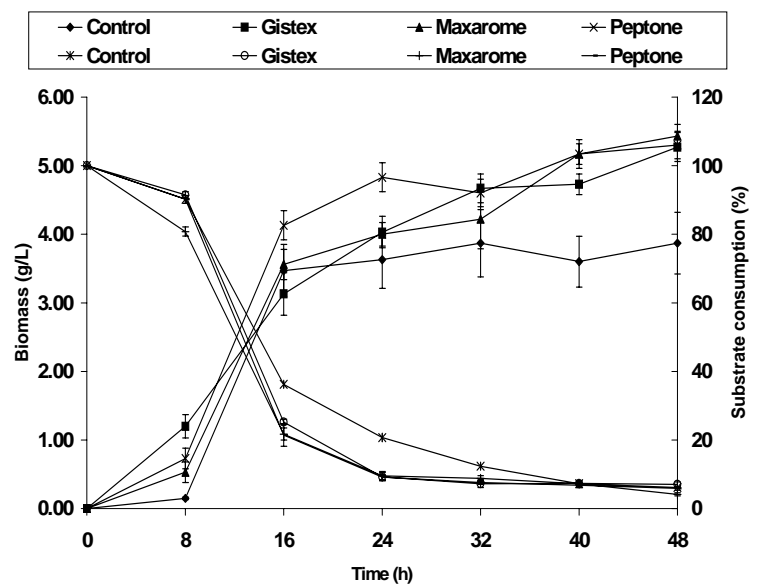

Figure 2: Effect of organic nitrogen source supplements on biomass $(\mathrm{g} / \mathrm{L})$ and remaining reducing sugar $(\mathrm{mg} / \mathrm{mL})$ of $C$. utilis grown in pineapple waste extracted medium at fixed concentration of $0.05 \%$ nitrogen content $(\mathrm{w} / \mathrm{v})$. Data are mean value \pm standard deviation of triplicate analysis of duplicate experiment

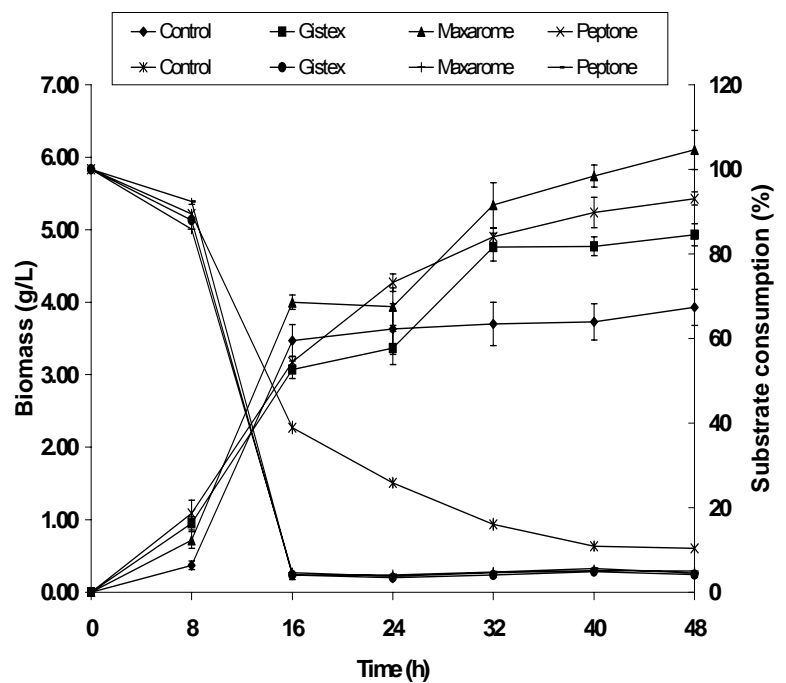

Figure 3: Effect of organic nitrogen source supplements on biomass $(\mathrm{g} / \mathrm{L})$ and remaining reducing sugar $(\mathrm{mg} / \mathrm{mL})$ of $C$. utilis grown in pineapple waste extracted medium at fixed concentration of $0.09 \%$ nitrogen content $(\mathrm{w} / \mathrm{v})$. Data are mean value \pm standard deviation of triplicate analysis of duplicate experiment 
While supplement of yeast extract Gistex increased biomass production by $10.3 \%$ and peptone was only $5.9 \%$. For the supplement of $0.05 \%$ nitrogen content, medium with Maxarome supplement increase the biomass production yield up to $38.3 \%$.

This is followed by peptone $(32.0 \%)$ and Gistex (29.1\%). When the nitrogen supplementation was increased to $0.09 \%(\mathrm{w} / \mathrm{v})$, Maxarome supplement enhanced biomass yield to $55.2 \%$, followed by peptone $(41.8 \%)$ while Gistex slightly declined to $28.7 \%$. Yield enhancement by yeast extract Maxarome are markedly observed at $0.09 \%$ nitrogen content compare to supplement of $0.01 \%$ and $0.05 \%$. However, substrate consumption turned up to be limitation of C. utilis growth when exceed $95 \%$ of substrate was utilized.

As biomass of yeast are mainly contributed by carbon, hydrogen, oxygen and nitrogen source from the provided medium (Bamforth, 2005). Hence, when the biomass yield increased with nitrogen supplementation, substrate usage will increase concurrently. From the data obtained, similar trend of substrate consumption for all type of nitrogen supplement can be observed. Nonetheless, substrate usage of control are significantly $(p<0.05)$ less than those fermentation with nitrogen supplement. At the same time, the substrate consumption increased significantly $(p<0.05)$ when the nitrogen supplementation increased from $0.01 \%$ $(\mathrm{w} / \mathrm{v})$ to $0.09 \%(\mathrm{w} / \mathrm{v})$ nitrogen content. Among the nitrogen sources added as supplement, $C$. utilis grown in medium with yeast extract Maxarome consumed the substrate most. This has shown that $C$. utilis grew well in this type of nitrogen source which produced highest biomass but consumed most substrate.

Yeast extract is the most commonly used nitrogen source in fermentation as it provides convenient growth factors for microbial growth (Nancib et al., 2001). The same as formulation of defined medium of YEPG which contains $2 \%$ of yeast extract. However, from the result obtained at higher nitrogen content supplement, Gistex is unfavourable compare to Maxarome and peptone; this may due to high salt content in yeast extract Gistex which approximately $39 \%$ (expressed on dry matter). This is much higher than yeast extract Maxarome (2\%). When the nitrogen content increased, salt content of Gistex supplement also increased. C. utilis unfavour to high salt condition (Martorell et al., 2007). In fact, Maxarome which has better quality is favour to $C$. utilis growth enhancement. However, high cost of yeast extract has it negative impact on the economics of its use in industrial-scale fermentation. In order to improve the economic parameters of yeast biomass production, effect of cheaper and comparable inorganic nitrogen sources were studied.

The effects of supplementing pineapple extracted juice with different inorganic nitrogen sources were compared. Each inorganic nitrogen source was supplemented in such an amount that it gave a nitrogen concentration of $0.01 \%$ $(w / v), 0.05 \%(w / v)$ and $0.09 \%(w / v)$ equivalent with organic source of nitrogen. The results showed that biomass production was markedly $(p<0.05)$ influenced by the type of nitrogen source and concentration, but all supplementation increased $(p<0.05)$ biomass production compared to the control which contained pineapple extracted juice only.

As for the fermentation medium with $0.01 \%(\mathrm{w} / \mathrm{v})$ nitrogen content, potassium nitrate, $\mathrm{KNO}_{3}$ showed the highest yield among the other sources, $26.6 \%$ of biomass yield increment compare to the control without any supplements (Figure 4). According to Kubisi et al. (1996), potassium nitrate is a naturally occurring mineral source of nitrogen, but only several yeasts are able to assimilate nitrate as a nitrogen source. Candida is one the species which its physiology and enzymology of nitrate assimilation of some species in general. Thus, potassium nitrate is suitable for $C$. utilis growth.

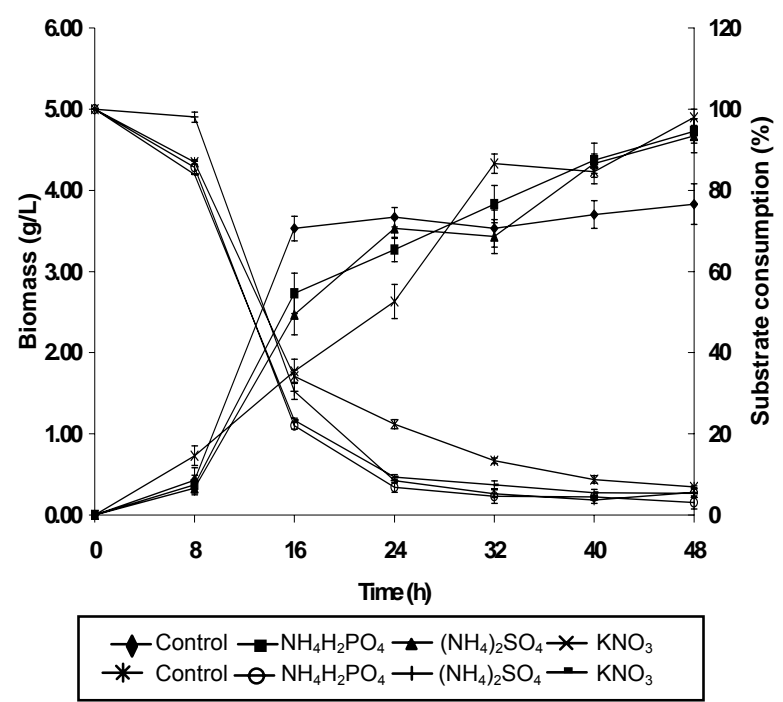

Figure 4: Effect of inorganic nitrogen source supplements on biomass $(\mathrm{g} / \mathrm{L})$ and remaining reducing sugar $(\mathrm{mg} / \mathrm{mL})$ of $C$. utilis grown in pineapple waste extracted medium at fixed concentration of $0.01 \%$ nitrogen content $(\mathrm{w} / \mathrm{v})$. Data are mean value \pm standard deviation of triplicate analysis of duplicate experiment

However, at the $0.05 \%(\mathrm{w} / \mathrm{v})$ concentration of nitrogen supplementation (Figure 5), ammonium dihydrogen phosphate salt, $\mathrm{NH}_{4} \mathrm{H}_{2} \mathrm{PO}_{4}$ surpassed potassium nitrate and ammonium sulphate and obtained highest yield among the others. It enhanced $37.8 \%$ of biomass yield compare to the control. According to Bamforth (2005), nitrogen in ammonium salt is readily assimilated by yeast. Lucca et al. (1995) reported that when C. utilis is grown in a glucoselimited, 'phosphate-deficient' continuous culture, its cell composition and morphology correlate with the phosphate 
concentration in the inflowing medium and the yeast's growth rate. The pineapple extracted medium which contains only low portion of phosphorus $(7 \mathrm{mg} / 100 \mathrm{~g})$ which may induce to phosphate deficient condition for culture. Thus, with supplement of $\mathrm{NH}_{4} \mathrm{H}_{2} \mathrm{PO}_{4}$ in fermentation medium, growth rate of increased. This phenomenon sustained when $0.09 \%(\mathrm{w} / \mathrm{v})$ nitrogen content (Figure 6) was added to fermentation medium. Biomass yield of medium with $\mathrm{NH}_{4} \mathrm{H}_{2} \mathrm{PO}_{4}$ achieved $53.7 \%$ enhancement which no significant different with yeast extracted Maxarome (Figure 3). Besides, ammonium sulphate salt, $\left(\mathrm{NH}_{4}\right)_{2} \mathrm{SO}_{4}$ which was added is a common and efficient nitrogen source for microbial growth. It is water soluble and does not produce a toxic effect towards majority of the enzymes. It also does not produce adverse effect towards the enzyme activity (Peppler, 1973; Bamforth, 2005). As it was applied to $C$. utilis fermentation, encouraging result was observed although it is not the best among those inorganic nitrogen sources. When $0.09 \%(\mathrm{w} / \mathrm{v})$ nitrogen content of $\left(\mathrm{NH}_{4}\right)_{2} \mathrm{SO}_{4}$ was added in fermentation medium, about $27.2 \%$ of biomass yield enhanced was obtained compared to control.
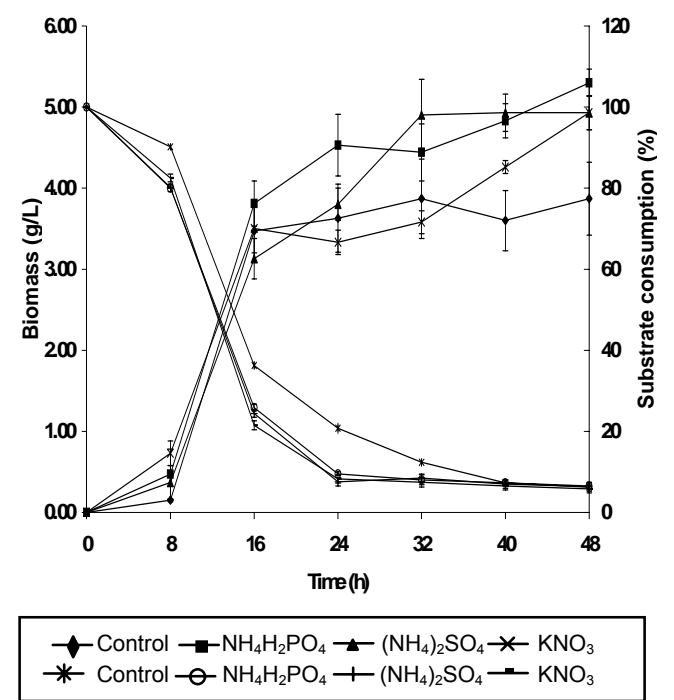

Figure 5: Effect of inorganic nitrogen source supplements on biomass $(\mathrm{g} / \mathrm{L})$ and remaining reducing sugar $(\mathrm{mg} / \mathrm{mL})$ of $C$. utilis grown in pineapple waste extracted medium at fixed concentration of $0.05 \%$ nitrogen content $(\mathrm{w} / \mathrm{v})$. Data are mean value \pm standard deviation of triplicate analysis of duplicate experiment

The results obtained show that biomass production increased with supplemented inorganic nitrogen content, reaching a maximum when the fermentation contained $0.09 \%(w / v)$ nitrogen content as depletion of carbon source become limitation of substrate usage available for yeast growth.

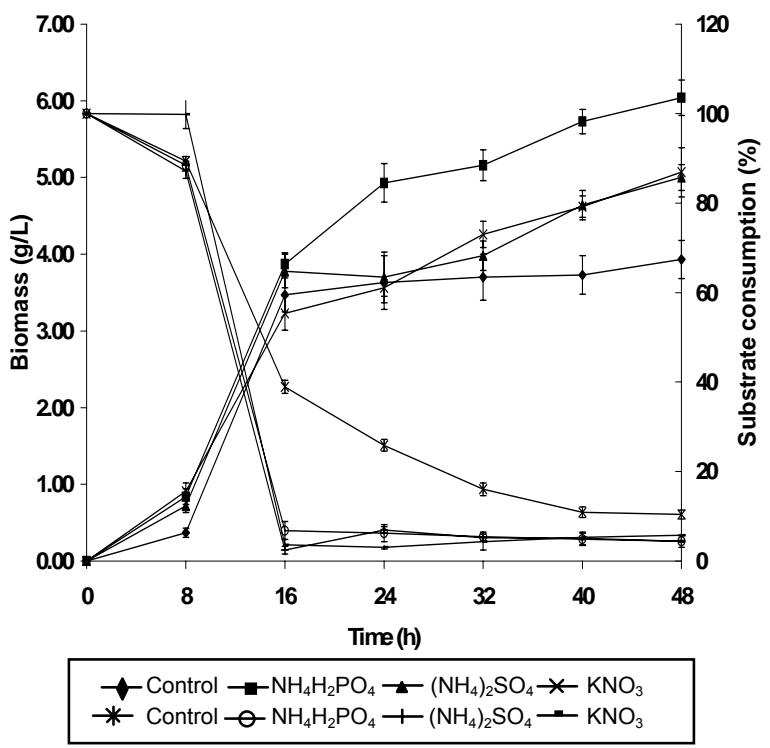

Figure 6: Effect of inorganic nitrogen source supplements on biomass $(\mathrm{g} / \mathrm{L})$ and remaining reducing sugar $(\mathrm{mg} / \mathrm{mL})$ of $C$. utilis grown in pineapple waste extracted medium at fixed concentration of $0.09 \%$ nitrogen content (w/v). Data are mean value \pm standard deviation of triplicate analysis of duplicate experiment

As shown in Figure 4-6, the percentage of substrate consumption increased dramatically after $8 \mathrm{~h}$ fermentation; as the yeast growth cycle entered exponential phase. Similar trend of substrate consumption can be observed from all type of fermentation medium, still the control which without any supplementation consumed less substrate than the others. In this case, substrate consumption which became limiting factor after fermentation $48 \mathrm{~h}$ can be control by continuously supply fresh medium into the fermenter (fed-batch) as sugar concentration is always kept low to obtain high cell yield compare to brewing which intend to have high yield of alcohol (Bamforth, 2005).

Total nitrogen content of selected fermented mediums was tested to justify the usage of nitrogen supplied to the fermentation by macro-Kjeldah method. Figure 7 showed the total nitrogen content at $0.05 \%(\mathrm{w} / \mathrm{v})$ nitrogen supplementation of each fermented medium and control which without supplement. Decreasing of nitrogen content was observed during fermentation from $0 \mathrm{~h}$ to $48 \mathrm{~h}$. After 24 $\mathrm{h}$ fermentation, medium with yeast extract treatment contained less nitrogen content compared to others. However, after $48 \mathrm{~h}$ fermentation, medium with peptone supplement was the least. 
Mal. J. Microbiol. Vol 3(1) 2007, pp. 19-26

Table 1: Effects of nitrogen sources with different concentration on C. utilis biomass yield, productivity and glucose consumption

\begin{tabular}{|c|c|c|c|c|c|c|c|c|c|c|c|c|}
\hline \multirow[b]{2}{*}{$\begin{array}{l}\text { Nitrogen } \\
\text { Content }\end{array}$} & \multicolumn{3}{|c|}{$\begin{array}{l}\text { Maximum biomass } \\
\text { (g/L media) }\end{array}$} & \multicolumn{3}{|c|}{$\begin{array}{c}\text { Yield of maximum biomass } \\
Y_{X / S}\left(10^{-1}\right)\end{array}$} & \multicolumn{3}{|c|}{ Productivity (g/L/h) $\left(10^{-1}\right)$} & \multicolumn{3}{|c|}{ Substrate Consumption (\%) } \\
\hline & $\begin{array}{l}0.01 \% \\
(w / v)\end{array}$ & $\begin{array}{l}0.05 \% \\
(w / v)\end{array}$ & $\begin{array}{l}0.09 \% \\
(w / v)\end{array}$ & $\begin{array}{l}0.01 \% \\
(w / v)\end{array}$ & $\begin{array}{l}0.05 \% \\
(w / v)\end{array}$ & $\begin{array}{l}0.09 \% \\
(w / v)\end{array}$ & $\begin{array}{l}0.01 \% \\
(w / v)\end{array}$ & $\begin{array}{l}0.05 \% \\
(w / v)\end{array}$ & $\begin{array}{l}0.09 \% \\
(w / v)\end{array}$ & $\begin{array}{l}0.01 \% \\
(w / v)\end{array}$ & $\begin{array}{l}0.05 \% \\
(w / v)\end{array}$ & $\begin{array}{l}0.09 \% \\
(w / v)\end{array}$ \\
\hline \multicolumn{13}{|l|}{ Treatments } \\
\hline Control & $\begin{array}{l}3.83 \pm \\
0.27^{\mathrm{aA}}\end{array}$ & $\begin{array}{l}3.87 \pm \\
0.35^{\mathrm{aA}}\end{array}$ & $\begin{array}{l}3.93 \pm \\
0.25^{\mathrm{aA}}\end{array}$ & $\begin{array}{l}1.86 \pm \\
0.12^{\mathrm{aA}}\end{array}$ & $\begin{array}{l}1.93 \pm \\
0.14^{\mathrm{aA}}\end{array}$ & $\begin{array}{l}2.45 \pm \\
0.14^{\mathrm{aB}}\end{array}$ & $0.80 \pm$ & $\begin{array}{l}0.81 \pm \\
0.07^{\mathrm{aA}}\end{array}$ & $\begin{array}{l}0.82 \pm \\
0.05^{\mathrm{aA}}\end{array}$ & $\begin{array}{l}93.12 \pm \\
0.32^{\mathrm{aB}}\end{array}$ & $\begin{array}{l}93.81 \pm \\
0.81^{\mathrm{aB}}\end{array}$ & $\begin{array}{l}89.58 \pm \\
0.98^{\mathrm{aA}}\end{array}$ \\
\hline $\begin{array}{l}\text { Yeast extract } \\
\text { (Gistex) }\end{array}$ & $\begin{array}{l}4.27 \pm \\
0.13^{\mathrm{bA}}\end{array}$ & $\begin{array}{l}5.27 \pm \\
0.21^{\mathrm{bcB}}\end{array}$ & $\begin{array}{l}4.93 \pm t \\
0.15^{\mathrm{b}}\end{array}$ & $\begin{array}{l}2.30 \pm \\
0.11^{\mathrm{bcA}}\end{array}$ & $\begin{array}{l}2.70 \pm \\
0.17^{\mathrm{cB}}\end{array}$ & $\begin{array}{l}2.38 \pm \\
0.09^{\mathrm{aA}}\end{array}$ & $\begin{array}{l}0.89 \pm \\
0.03^{\mathrm{ab} A}\end{array}$ & $\begin{array}{l}1.10 \pm \\
0.04^{\mathrm{b}}\end{array}$ & $\begin{array}{l}1.03^{ \pm \pm} \\
0.03^{b}\end{array}$ & $\begin{array}{l}94.52 \pm \\
0.51^{\mathrm{ab} A}\end{array}$ & $\begin{array}{l}92.95 \pm \\
0.79^{\mathrm{aB}}\end{array}$ & $\begin{array}{l}95.82 \pm \\
0.87^{\mathrm{bB}}\end{array}$ \\
\hline $\begin{array}{l}\text { Yeast Extract } \\
\text { (Maxarome) }\end{array}$ & $\begin{array}{l}4.97 \pm \\
0.25^{\mathrm{cA}}\end{array}$ & $\begin{array}{l}5.43 \pm \\
0.16^{\mathrm{cA}}\end{array}$ & $\begin{array}{l}6.10 \pm \\
0.17^{\mathrm{dB}}\end{array}$ & $\begin{array}{l}2.51 \pm \\
0.18^{\mathrm{cA}}\end{array}$ & $\begin{array}{l}2.69 \pm \\
0.17^{\mathrm{cA}}\end{array}$ & $\begin{array}{l}3.23 \pm \\
0.10^{\mathrm{bcB}}\end{array}$ & $\begin{array}{l}1.03 \pm \\
0.05^{\mathrm{cA}}\end{array}$ & $\begin{array}{l}1.13 \pm \\
0.03^{\mathrm{bA}}\end{array}$ & $\begin{array}{l}1.27 \pm \\
0.03^{\mathrm{CB}}\end{array}$ & $\begin{array}{l}94.85 \pm \\
0.65^{\mathrm{abA}}\end{array}$ & $\begin{array}{l}95.82 \pm \\
2.20^{\mathrm{bA}} \pm\end{array}$ & $\begin{array}{l}95.00 \pm \\
0.44^{\mathrm{bA}}\end{array}$ \\
\hline Peptone & $\begin{array}{l}4.17 \stackrel{ \pm}{ \pm} \\
0.15^{\mathrm{bA}}\end{array}$ & $\begin{array}{l}5.30 \pm \\
0.13^{\mathrm{bcB}}\end{array}$ & $\begin{array}{l}5.43 \pm \pm \\
0.09^{\mathrm{cB}}\end{array}$ & $\begin{array}{l}2.14 \pm t \\
0.03^{\mathrm{bA}}\end{array}$ & $\begin{array}{l}2.80 \pm \\
0.02^{\mathrm{CB}}\end{array}$ & $\begin{array}{l}3.00 \pm \pm \\
0.02^{\mathrm{bc}}\end{array}$ & $\begin{array}{l}0.87 \pm \\
0.03^{\mathrm{aA}}\end{array}$ & $\begin{array}{l}1.10 \pm \\
0.03^{b \mathrm{~B}}\end{array}$ & $\begin{array}{l}1.13^{\mathrm{t}} \\
0.02^{\mathrm{b}}\end{array}$ & $\begin{array}{l}95.05 \pm \\
1.13^{\mathrm{bA}} \pm\end{array}$ & $\begin{array}{l}94.11 \pm \\
0.99^{\mathrm{aA}}\end{array}$ & $\begin{array}{l}95.45 \pm \\
1.04^{\mathrm{bA}}\end{array}$ \\
\hline $\begin{array}{l}\text { Ammonium } \\
\text { dihydrogen } \\
\text { phosphate, } \\
\mathrm{NH}_{4} \mathrm{H}_{2} \mathrm{PO}_{4}\end{array}$ & $\begin{array}{l}4.73 \pm \\
0.15^{\mathrm{cA}}\end{array}$ & $\begin{array}{l}5.30 \pm \\
0.17^{\mathrm{bcB}}\end{array}$ & $\begin{array}{l}6.04 \pm \\
0.23^{\mathrm{dC}}\end{array}$ & $\begin{array}{l}2.29 \pm \\
0.01^{\mathrm{bcA}}\end{array}$ & $\begin{array}{l}2.76 \pm \\
0.08^{\mathrm{cB}}\end{array}$ & $\begin{array}{l}3.39 \pm \\
0.12^{\mathrm{cC}}\end{array}$ & $\begin{array}{l}0.99 \pm \\
0.03^{\mathrm{cA}}\end{array}$ & $\begin{array}{l}1.10 \pm \\
0.03^{\mathrm{bB}}\end{array}$ & $\begin{array}{l}1.26 \pm \\
0.05^{\mathrm{cC}}\end{array}$ & $\begin{array}{l}95.66 \pm \\
1.60^{\mathrm{bB}}\end{array}$ & $\begin{array}{l}93.50 \pm \\
0.76^{\mathrm{aA}}\end{array}$ & $\begin{array}{l}95.59 \pm \\
0.22^{\mathrm{bB}}\end{array}$ \\
\hline $\begin{array}{l}\text { Ammonium } \\
\text { sulphate, } \\
\left(\mathrm{NH}_{4}\right)_{2} \mathrm{SO}_{4}\end{array}$ & $\begin{array}{l}4.67 \pm \\
0.19^{\mathrm{cA}}\end{array}$ & $\begin{array}{l}4.93 \pm \\
0.21^{\mathrm{bA}}\end{array}$ & $\begin{array}{l}5.00 \pm \\
0.21^{\mathrm{bA}}\end{array}$ & $\begin{array}{l}2.30 \pm \\
0.04^{\mathrm{bcA}}\end{array}$ & $\begin{array}{l}2.43 \pm \\
0.16^{\mathrm{bA}}\end{array}$ & $\begin{array}{l}2.99 \pm \\
0.08^{\mathrm{bB}}\end{array}$ & $\begin{array}{l}0.97 \pm \\
0.04^{\mathrm{bcA}}\end{array}$ & $\begin{array}{l}1.03 \pm \\
0.04^{\mathrm{bA}}\end{array}$ & $\begin{array}{l}1.04 \pm \\
0.04^{\mathrm{bA}}\end{array}$ & $\begin{array}{l}94.96 \pm \\
1.17^{\mathrm{abA}}\end{array}$ & $\begin{array}{l}93.65 \pm \\
1.04^{\mathrm{aA}}\end{array}$ & $\begin{array}{l}95.57 \pm \\
1.08^{\mathrm{bA}}\end{array}$ \\
\hline $\begin{array}{l}\text { Potassium } \\
\text { nitrate, } \mathrm{KNO}_{3}\end{array}$ & $\begin{array}{l}4.90 \pm \\
0.12^{\mathrm{CA}}\end{array}$ & $\begin{array}{l}4.93 \pm \\
0.23^{\mathrm{bA}}\end{array}$ & $\begin{array}{l}5.07 \pm \\
0.32^{\mathrm{bcA}}\end{array}$ & $\begin{array}{l}2.31 \pm \\
0.09^{\mathrm{bcA}}\end{array}$ & $\begin{array}{l}2.36 \pm \\
0.17^{\mathrm{bA}}\end{array}$ & $\begin{array}{l}3.21 \pm \\
0.25^{\mathrm{bcB}}\end{array}$ & $\begin{array}{l}1.02 \pm \\
0.03^{\mathrm{CA}}\end{array}$ & $\begin{array}{l}1.03 \pm \\
0.05^{\mathrm{bA}}\end{array}$ & $\begin{array}{l}1.06 \pm \\
0.07^{\mathrm{bA}}\end{array}$ & $\begin{array}{l}95.54 \pm \\
1.05^{\mathrm{bA}}\end{array}$ & $\begin{array}{l}94.20 \pm \\
0.55^{\mathrm{aA}}\end{array}$ & $\begin{array}{l}94.22 \pm \\
0.16 \mathrm{bA}\end{array}$ \\
\hline
\end{tabular}

$\mathrm{Y}_{\mathrm{X} / \mathrm{S}}=\mathrm{g}$ biomass per reducing sugar utilized

Productivity $=\mathrm{g}$ maximum biomass per corresponding fermentation time

Results are the average of data coming from triplicate experiments with S.D.

Control was the blank medium which ran parallel with each batch of treatment.

Values with the same superscript alphabet in the same column do not differ significantly among each other ( $p>0.05$ ) according to Duncan's multiple range test.

Values with the same superscript (capital) alphabet in the same row do not differ significantly among each other ( $p>0.05)$ according to Duncan's multiple range test. 


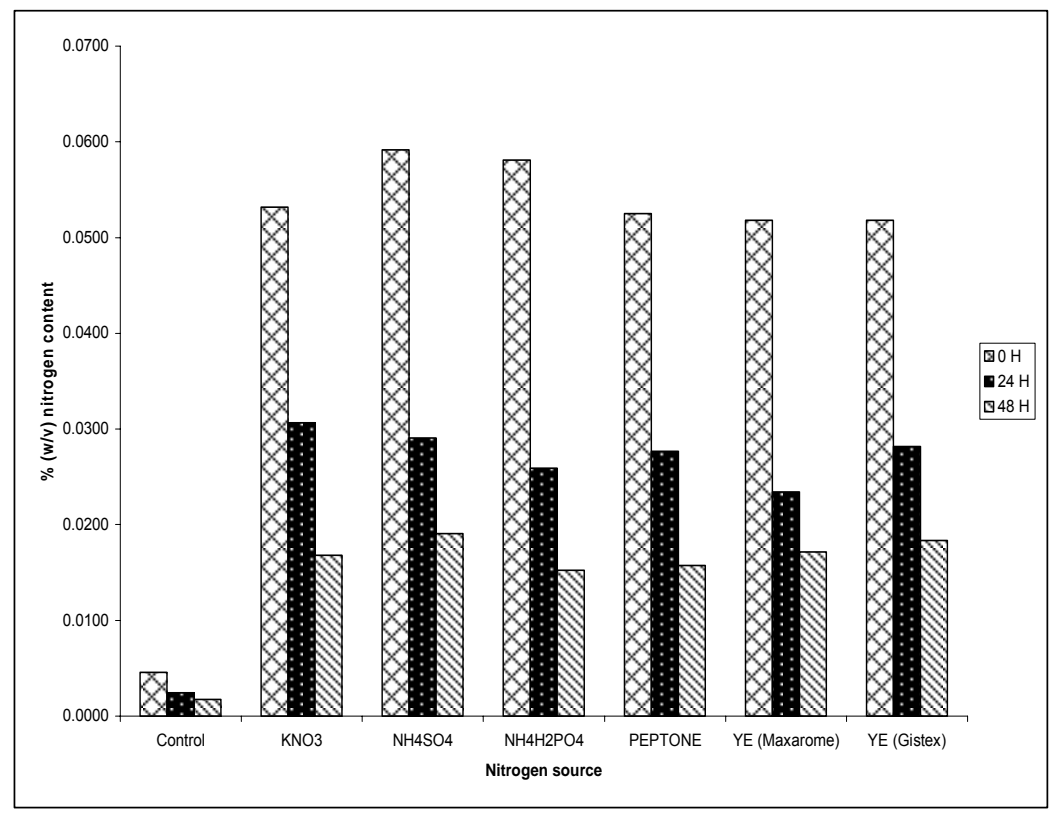

Figure 7: Total nitrogen content of different sources in fermentation medium during fermentation time $0 \mathrm{~h}, 24 \mathrm{~h}$ and $48 \mathrm{~h}$. Each treatment expressed in nitrogen equivalent at $0.05 \%$ nitrogen content $(\mathrm{w} / \mathrm{v})$

Table 1 shows the summary of maximum biomass, yield of maximum biomass, productivity and glucose consumption of fermentation medium with different types and concentrations of nitrogen source supplements. The result obtained pointed out that addition of nitrogen supplements enhanced the growth of $C$. utilis significantly $(p<0.05)$ when compared to control. Subsequently, yield of biomass and productivity were increased as well. Among the organic nitrogen sources, yeast extract of Maxarome gained the highest yield of fermentation biomass and productivity. While inorganic source, ammonium dihydrogen phosphate $\left(\mathrm{NH}_{4} \mathrm{H}_{2} \mathrm{PO}_{4}\right)$ increased the biomass, yield and productivity the most compare to the others. The medium composition which is optimal in terms of maximal consumption of nutrients by the microorganism, might not be optimal in terms of the quality of the resulting biomass of the volumetric productivity of the production process (Lucca et al., 1995). This is because substrate consumption can be utilized for cell metabolism and metabolite like enzyme was produced.

\section{CONCLUSION}

Both organic and inorganic source of nitrogen enhanced biomass production. Among the type of nitrogen sources evaluated, yeast extract Maxarome and ammonium dihydrogen phosphate are the best compared to others. At concentration of $0.09 \%(w / v)$ nitrogen content, biomass production obtained was highest.

\section{ACKNOWLEDGEMENT}

Authors are grateful to funding of Terengganu government state grant and the National Science Fellowship (NSF) of Ministry of Science, Technology and Innovation for their financial assistance.

\section{REFERENCES}

Bamforth, C.W. (2005). Food, fermentation and microorganisms. Blackwell Science Ltd. Oxford. p. 1 - 38.

Belem, M.A.F., Gibbs, B.F. and Lee, B.H. (1997). Enzymatic production of ribonucleotides from autolysates of Kluyveromyces marxianus grown on whey. Journal of Food Science 62(4): 851 - 857.

Kouakou, A., Agbo, N.G. and Yeboua, A. (1987). Ethanol production from pineapple juice in côte d'ivoire with preselected yeast strains. Journal of Fermentation Technology 65 (4): 475 - 481.

Kubisi, A.A., Ali, A.H. and Hipkin, C.R. (1996). Nitrite assimilation by the yeast Candida nitratophila New Phytologist 132: 313 - 316. 
Lee, B.K. and Kim, J.K. (2001). Production of Candida utilis biomass on molasses in different culture types. Aquacultural Engineering 25: 111 - 124.

Loo, C.Y., Rosma, A., Mohd Azemi, M.N. and Wan Nadiah, W.A. (2002). Influence of agrowaste media on intracellular protein of Saccharomyces cerevisiae and Candida utilis. 25th Malaysian Microbiology Symposium and 5th UNESCO National Workshop for the Promotion of microbiology in Malaysia. pp.

Lucca, M.E., Romero, M.E. and Callieri, D.A.S. (1995). Continuous culture of candida utilis: Influence of medium nitrogen concentration. World Journal of Microbiology \& Biotechnology 11: 515 - 518.

Martorell, P., Stratford, M., Steels, H., FernándezEspinar, M.T. and Querol, A. (2007). Physiological characterization of spoilage strains of Zygosaccharomyces bailii and Zygosaccharomyces rouxii isolated from high sugar environments. International Journal of Food Microbiology 114: 234 242.

Mohd Azemi, M.N., Suraimi, M., Rosma, A. and Amiza, M.A. (2001). The production of yeast cells from palm oil mill effluent (pome). Proceedings of USM-JIRCAS Joint International Symposium, Penang, Malaysia, pp. 67- 75.

Nagodawithana, T. (1992). Yeast-derived flavor enhancer and their probable mode of action. Food Technology 46(11): 138 - 143.

Nancib, N., Nancib, A., Boudjelal, A., Benslimane, C., Blanchard, F. and Boudrant, J. (2001). The effect of supplementation by different nitrogen sources on the production of lactic acid from date juice by Lactobacillus casei subsp. Rhamnosus. Bioresource Technology 78: 149 - 153.

Nigam, J.N. (1999). Continuous ethanol production from pineapple cannery waste. Journal of Biotechnology 72 : 197 - 202.

Peppler, H.J. (1973). Yeast technology. In: Microbial technology. Peppler, H. J. (ed.) Reinhold Publishing Corporation, New York. p. 145 - 287.

Roukas, T. (1996). Ethanol production from non-sterilized beet molasses by free and immobilized Saccharomyces cerevisiae cells using fed-batch culture. Journal of Food Engineering 27: 87 - 96.

Sommer, R. (1998). Yeast extracts: Production, properties and components. Food Australia 50(4): 181 - 183.

Stanbury, P.F., Whitaker, A. and Hall, S.J. (1995). Principles of fermentation technology. Pergamon. UK. p. 1 - 24.

Zheng, S.K., Yang, M. and Yang, Z.F. (2005a). Biomass production of yeast isolate from salad oil manufacturing wastewater. Bioresource Technology 96: 1183 - 1187.

Zheng, S.K., Yang, M., Yang, Z.F. and Yang, Q.X. (2005b). Biomass production from glutamate fermentation wastewater by the co-culture of Candida halophila and Rhodotorula glutinis. Bioresource Technology 96: 1522 - 1524. 